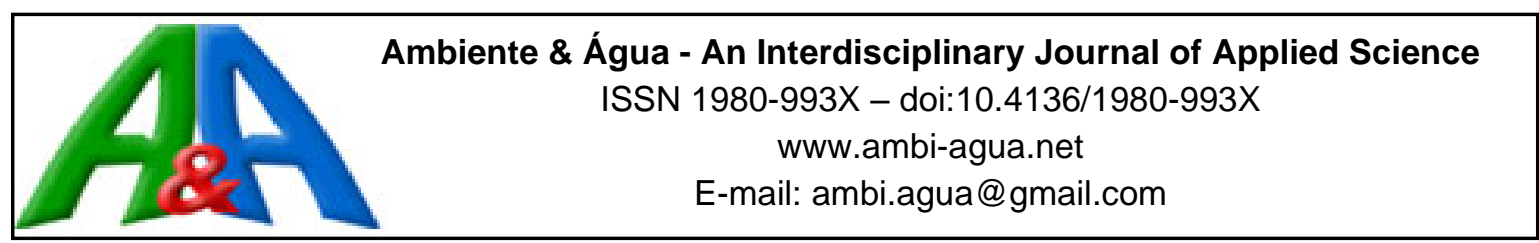

\title{
Interaction of precipitation with tree canopy increases nutrient input
}

\author{
ARTICLES doi:10.4136/ambi-agua.2761
}

Received: 20 Jun. 2021; Accepted: 04 Oct. 2021

\begin{abstract}
Gian Carlos Poleto ${ }^{1}$; ; Dione Richer Momolli ${ }^{1 *}$; Mauro Valdir Schumacher ${ }^{1}{ }^{(D)}$; Aline Aparecida Ludvichak ${ }^{1}$; Kristiana Fiorentin dos Santos ${ }^{2}$; Márcio Viera ${ }^{1}$; Clayton Alcarde Alvares ${ }^{3}$ iD; James Stahl ${ }^{4}$ id

${ }^{1}$ Universidade Federal de Santa Maria (UFSM), Avenida Roraima, n 1000, CEP: 97105-900, Santa Maria, RS, Brazil.E-mail: gianpoleto@gmail.com, mauro.schumacher@ufsm.br, aline_lud@yahoo.com.br, marcio.viera@ufsm.br

${ }^{2}$ Departamento de Engenharia Florestal. Universidade Regional de Blumenau (FURB), Rua São Paulo, n 3250, CEP: 89030-000, Blumenau, SC, Brazil. E-mail: kristianafiorentin@ gmail.com

${ }^{3}$ Suzano SA, Estrada Limeira, n 391, CEP: 13465-970, Limeira, SP, Brazil. E-mail: calcarde@ suzano.com.br ${ }^{4}$ Klabin S.A., Unidade de Monte Alegre, Avenida Brasil, n 26, CEP: 84275-000, Telêmaco Borba, PR, Brazil. E-mail: jstahl@klabin.com.br

*Corresponding author. E-mail: dionemomolli@gmail.com
\end{abstract}

\begin{abstract}
Given that atmospheric deposition is the first source of nutrient input into forest ecosystems, and that the precipitation partition serves as a nutritional source mainly when there is an interaction with the forest canopy, the objective of the present study was to quantify the nutrients input into rainfall, throughfall and stemflow in Eucalyptus urophylla stands with partial exclusion (E) and without exclusion (WE) of throughfall. The experiment was conducted in the northeast of the state of Paraná-Brazil, in the municipality of Telêmaco Borba. The partial precipitation exclusion system (E) is formed by a system of gutters that conduct $30 \%$ of throughfall out of the experiment. The nutrient input in rainfall was $55.7 \mathrm{~kg} \mathrm{ha}^{-1} \mathrm{yr}^{-1}$, while the sum of throughfall and stemflow was $64.1 \mathrm{~kg} \mathrm{ha}^{-1} \mathrm{yr}^{-1}$ in treatment (WE) and $39.8 \mathrm{~kg} \mathrm{ha}^{-1} \mathrm{yr}^{-1}$ in treatment (E). Interaction with the canopy of the trees enriched the rainfall with nutrients, mainly the elements potassium and chlorine, due to leaching of the vegetal tissues. The reduction of the water treatment system in partial exclusion of precipitation (E) reduced representative nutrient input. Although stemflow represents on average only $2.6 \%$ of the water volume, it is responsible for $6.7 \%$ of the amount of nutrients in relation to precipitation. Therefore, stemflow cannot be neglected in the balance of nutrient cycling. With a rotation of 7 years, the application of significant amounts of fertilizers can be avoided, considering the inputs of 449 and $277 \mathrm{~kg} \mathrm{ha}^{-1} \mathrm{year}^{-1}$.
\end{abstract}

Keywords: nutrient cycling, stemflow, throughfall.

\section{Interação da precipitação com o dossel florestal aumenta o aporte de nutrientes}

\section{RESUMO}

Sabendo que a deposição atmosférica é a primeira fonte de entrada de nutrientes nos ecossistemas florestais e que a partição de precipitação serve como fonte nutricional principalmente quando há interação com o dossel florestal, o objetivo do presente estudo foi 
quantificar o aporte de nutrientes na precipitação incidente, precipitação interna e escoamento pelo tronco em um povoamento de Eucalyptus urophylla com exclusão parcial (E) e sem exclusão parcial (WE) da precipitação interna. O experimento está localizado no nordeste do estado do Paraná-Brasil, no município de Telêmaco Borba. O sistema de exclusão parcial de precipitação (E) é formado por um sistema de calhas que conduzem $30 \%$ da precipitação interna para fora do experimento. $\mathrm{O}$ aporte de nutrientes pela precipitação incidente foi de $55.7 \mathrm{~kg} \mathrm{ha}^{-}$ ${ }_{1}$ ano $^{-1}$, enquanto que a soma dos mesmos na precipitação interna e escoamento pelo tronco foram de $39.8 \mathrm{~kg} \mathrm{ha}^{-1} \mathrm{ano}^{-1}$ no tratamento com exclusão (E) e de $64.1 \mathrm{~kg} \mathrm{ha}^{-1} \mathrm{ano}^{-1}$ no tratamento sem exclusão (WE). A interação com o dossel florestal enriquece com nutrientes especialmente com os elementos potássio e cloro devido a lixiviação dos tecidos vegetais. A redução do regime hídrico no tratamento com exclusão parcial da precipitação (E) reduziu de forma representativa a entrada de nutrientes. Embora o escoamento pelo tronco represente em média apenas $2.6 \%$ do volume de água, ele é responsável por $6.7 \%$ da quantidade de nutrientes em relação à precipitação. Portanto, o mesmo não pode ser negligenciado no balanço da ciclagem de nutrientes. Com uma rotação de 7 anos a aplicação de importantes quantidades de fertilizantes podem ser evitados considerando as entradas de 449 e $277 \mathrm{~kg} \mathrm{ha}^{-1} \mathrm{ano}^{-1}$.

Palavras-chave: ciclagem de nutrientes, escoamento pelo tronco, precipitação interna.

\section{INTRODUCTION}

The forestry sector has occupied a prominent position in the Brazilian economy. Planted forests occupy 9.0 million hectares of the country and the genus Eucalyptus represents $77 \%$ of this area. Even with the large area occupied, the industrial forest plantations cover about $0.92 \%$ of the Brazilian territory. Paper and cellulose commodities occupy the second place in the list of products most exported by Brazil (IBÁ, 2020).

Extensive areas occupied by forest plantations are able to modify the hydrological balance (Ferraz et al. 2019). The partition of the rainfall in the area covered by vegetation is very dynamic. During precipitation, a portion of the water is intercepted by the canopy and immediately evaporated into the atmosphere (Llorens and Domingo, 2007). Part of the precipitation crosses the canopy and drips into the stand; this is called "throughfall" (Navar, 2011). A portion of the throughfall flows from the leaves to the branches and trunk, reaching the base of the tree; this portion is called "stemflow" (Zhang et al., 2016; Johnson and Lehmann, 2006). The knowledge of the partition of precipitation is important in studies of modeling the water balance of a watershed; however, many studies have considered a generic value for the index of canopy interception (Chaffe et al., 2010).

Many studies show the importance of the partition of precipitation in the biogeochemical cycle of nutrients (Staelens et al., 2006; Fan et al., 2015). Some studies also point out that the productivity and stability of a forest ecosystem is determined by the cycling of nutrients (Likens 2013). According to Viera and Schumacher (2010), part of the input of nutrients into an ecosystem occurs through precipitation that carries dust particles from the atmosphere to the ground. In addition, when interacting with the canopy of the trees, precipitation leaches the different tissues of the plant, increasing the nutritional contribution (Schrumpf et al., 2006; Bhat et al., 2011; Levia et al., 2011). Thus, precipitation is responsible for providing information regarding environmental quality (Zhou et al., 2019). In addition, soils from areas of low natural fertility, the entry of nutrients by precipitation may be the only nutritional source (Dawoe et al., 2018; Lu et al., 2017).

The chemical composition of throughfall and stemflow is influenced by the interaction of water with the forest canopy, distance from the sea and anthropogenic activities (Andre et al., 2008; Navar et al., 2009; Tiwari et al., 2016). In general, these pathways provide an important 
nutritional source for tree roots, especially with cation enrichment (Zhang et al., 2013; Su et $a l ., 2019)$. Although the stemflow represents a small portion of the volume of water that reaches the forest soil, this solution is responsible for accelerating the redistribution of nutrients and changing the physico-chemical properties in the root region (Swaffer et al., 2014; Momolli et al. 2019b)

Climate change has caused great variation in the rainfall regime (Allan and Soden, 2008), in addition, the water regime in southern Brazil is determined by atmospheric-oceanic phenomena. When equatorial waters in the Pacific Ocean cool, the phenomenon of "La Niña" occurs, which is responsible for the significant decrease in rainfall in this region. As a consequence, there is a loss of productivity of several crops, including those of Eucalyptus plantations. This study evaluates nutrient input into rainfall, throughfall and stemflow in a Eucalyptus stand with and without partial exclusion of throughfall.

\section{MATERIALS AND METHODS}

\subsection{Characterization of the experimental area}

The experimental area is located in the northeast region of the state of Paraná, in the municipality of Telêmaco Borba, under the geographic coordinates $24^{\circ} 13^{\prime} 41.0^{\prime \prime} \mathrm{S}$ and $50^{\circ} 31^{\prime} 40.0$ " W. The climate classification is Cfb (temperate climate), with an average annual temperature of $18.8^{\circ} \mathrm{C}$ and an average annual precipitation of $1646 \mathrm{~mm}$, according to the Köppen classification (Alvares et al., 2014). According to Flores et al. (2016) the species $E$. urophylla is classified as having low climatic aptitude for the study region.

Figure 1 shows meteorological data for the period from July 2017 to June 2018, obtained from the meteorological station located at the company Klabin SA in Telêmaco Borba - PR Brazil at $880 \mathrm{~m}$ altitude, $24^{\circ} 12^{\prime} 40.6^{\prime \prime} \mathrm{S}$ and 50 33'29.2" $\mathrm{W}$. The distance between the experimental area and the weather station is approximately $3.4 \mathrm{~km}$ in a straight line.

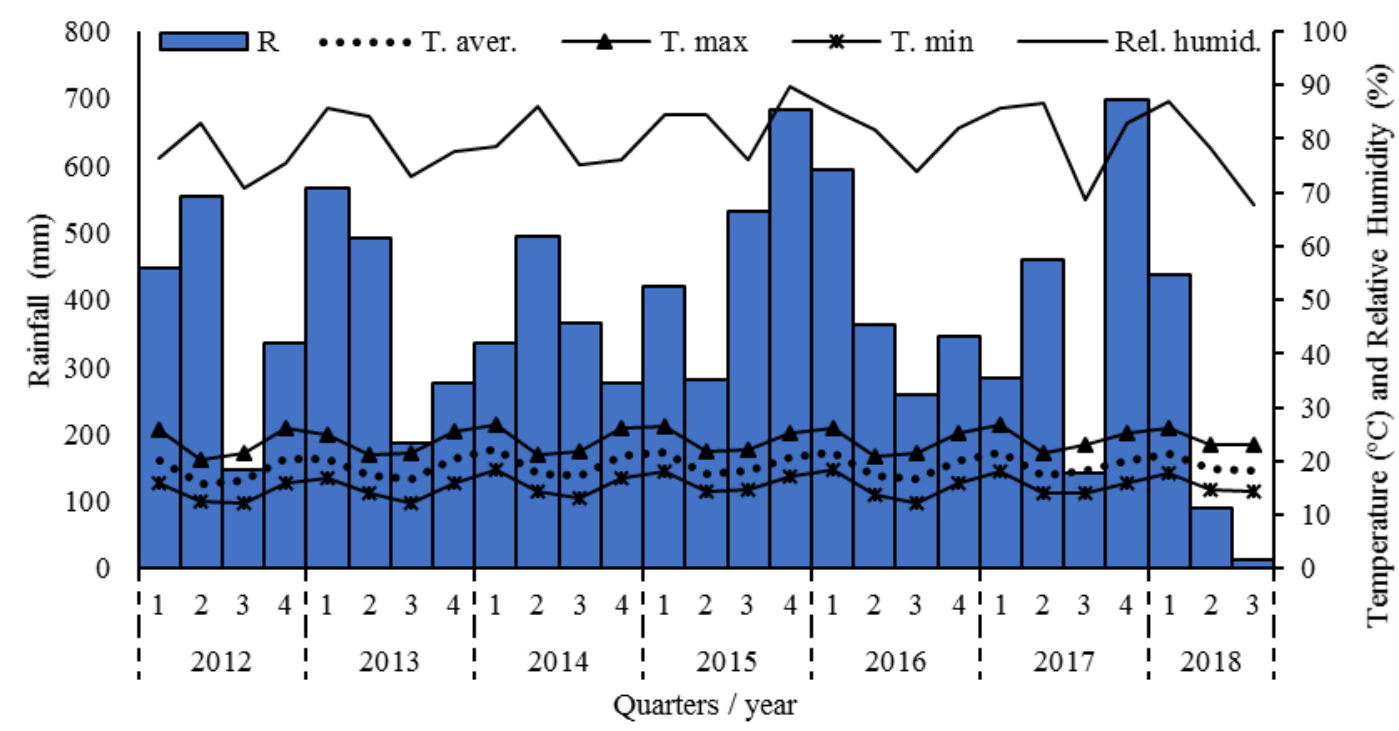

Figure 1. Weather data for the municipality of Telêmaco Borba, PR during the study period.

In March 2017, dendrometric characterization was performed, measuring the height and diameter at breast height $(\mathrm{DBH})$ of all trees. The mean $\mathrm{DBH}$ and the total height in the Exclusion (E) treatment were $16.8 \mathrm{~cm}$ and $28.6 \mathrm{~m}$, respectively. For the Without Exclusion (WE) treatment, the mean DBH was $17.3 \mathrm{~cm}$ and the total height $28.3 \mathrm{~m}$. The volume per hectare in the E and WE treatment was 346 and $365 \mathrm{~m}^{3} \mathrm{ha}^{-1}$, respectively. The leaf area index was 2.95 and 2.82 for treating exclusion (E) and without exclusion (WE), respectively. 


\subsection{Experimental design}

The study belongs to the TECHS project (Tolerance of Eucalyptus Clones to Hydric, Thermal and Biotic Stresses). The experiment was carried out in a completely randomized design, with $720 \mathrm{~m}^{2}$ plots of eight lines with ten plants each in spacing of $3 \mathrm{~m} \times 3 \mathrm{~m}(1,111$ trees ha-1). For the hybrid E. urophylla x E. sp. two treatments of the water regime were defined: one receiving $100 \%$ of the throughfall (WE) and the other receiving only $70 \%$ of the throughfall (E). For the treatment (E) that received $70 \%$ of the precipitation, a system of partial exclusion of the throughfall was used with plastic gutters that prevented the precipitation reaching the ground. A schematic representation of the precipitation exclusion treatment (E) can be seen in Figure 2. This technique is based on the coverage between the planting lines covering $216 \mathrm{~m}^{2}$ of the area of each treatment, being the equivalent to $30 \%$ of the plot area (Binkley et al., 2017).

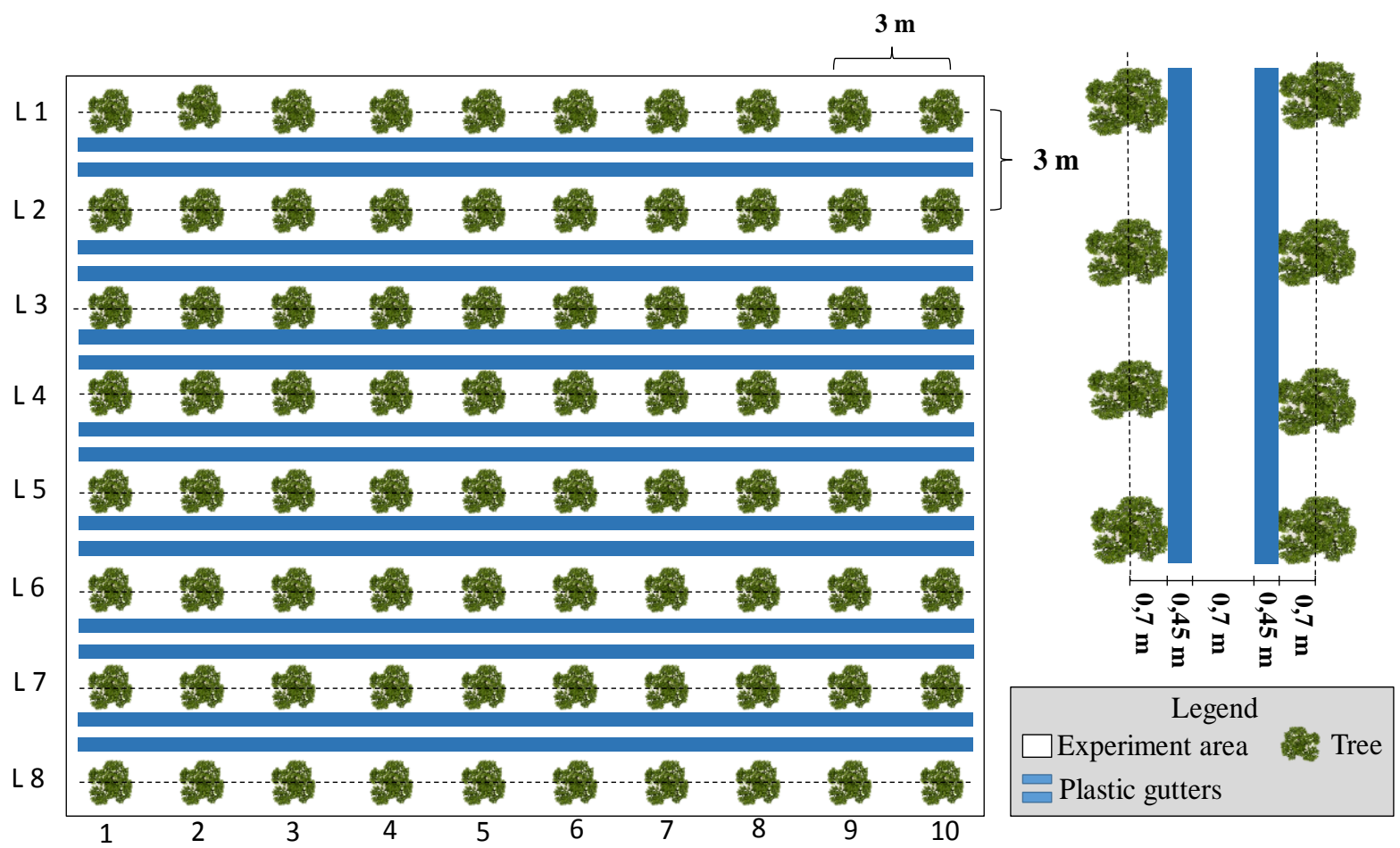

Figure 2. Representative scheme of the partial precipitation exclusion treatment (E), with dimensions and spacing.

The monitoring of the partition of precipitation under the two rainfall regimes occurred from July 2017 to June 2018. Sampling was started when the stand was 66 months old. For the (E) treatment, a partial exclusion system of throughfall was used, installed when the stand was one year old.

\subsection{Measurement of rainfall, throughfall and stemflow}

To quantify the rainfall $(\mathrm{R})$, three collectors with a $20 \mathrm{~cm}$ catchment diameter were installed in an area adjacent to the eucalyptus stand at a height of $1.5 \mathrm{~m}$ above ground level. Straps with steel wires were placed in order to prevent birds from using the collectors as perches.

For the evaluation of throughfall (Tf), nine collectors per treatment were installed, with a collection diameter of $20 \mathrm{~cm}$ and height of $1 \mathrm{~m}$ from ground level, systematically distributed along the line, between the lines and diagonally between four trees. Collections were started at 66 months of age. 
The stemflow quantification (Sf) occurred with the installation of nine sets formed by a plastic hose with a diameter of one inch and a reservoir for water storage. The hose was cut longitudinally and then it was installed in a spiral shape on the tree trunk. This configuration allowed the water to drain through the trunk and be stored in the reservoir.

Bi-weekly, the values of rainfall (R), throughfall (Tf) and stemflow (Sf) were measured. To obtain the values of precipitation and throughfall in millimeters, the following Equation 1 was used:

$R=V / a$

Where:

$\mathrm{R}=$ rainfall (mm);

$\mathrm{V}=$ volume collected $(\mathrm{L})$;

$\mathrm{a}=$ collector area $\left(\mathrm{m}^{2}\right)$.

The values of stemflow were obtained using the following Equation 2, used by Preuhsler et al. (2006):

$S f=\left(\frac{V}{g}\right) *\left(\frac{G}{A}\right)$

Where:

$\mathrm{Sf}=$ stemflow $(\mathrm{mm})$;

$\mathrm{V}=$ volume collected $(\mathrm{L})$;

$\mathrm{g}=$ basal area of the tree $\left(\mathrm{m}^{2}\right)$;

$\mathrm{G}=$ basal area of the plot $\left(\mathrm{m}^{2}\right)$;

$A=$ plot area $\left(m^{2}\right)$.

For the canopy interception calculation, the Equation 3 was used:

$I=\frac{R-(T f+S f)}{R} * 100$

Where:

$\mathrm{I}=$ canopy interception $(\%)$;

$\mathrm{R}=$ rainfall (mm);

$\mathrm{Tf}=$ throughfall $(\mathrm{mm})$;

$\mathrm{Sf}=$ stemflow $(\mathrm{mm})$.

The rainfall and throughfall collectors were composed of plastic bottles with a capacity of 2 liters, and the collections were carried out every 15 days. The throughfall collectors were arranged on the line, between the lines and diagonally between four trees. The stemflow samples were also collected for chemical analysis every 15 days.

\subsection{Statistics and Data Analysis}

The rainfall, throughfall and stemflow samples were sent to the Forest Ecology Laboratory where the $\mathrm{pH}$ was determined. For this variable, the electrode (Methohm $827 \mathrm{pH}$ LAB) was used, and filtered with a $0.45 \mu \mathrm{m}$ pore filter. According to the methodology proposed by the 
American Public Health Association (APHA et al., 1998), $\mathrm{NO}_{2}^{-}, \mathrm{NO}_{3}^{-}, \mathrm{PO}_{4}{ }^{3-}, \mathrm{SO}_{4}^{-}, \mathrm{Cl}^{-}, \mathrm{K}^{+}, \mathrm{Ca}^{2+}$ and $\mathrm{Mg}^{2+}$ ions were analyzed, with a pre-treatment with simple filtration followed by ion chromatography. The amount of nutrient input is given by multiplying the concentrations of ions ( $\left.\mathrm{mg} \mathrm{L}^{-1}\right)$ by the volume (liters).

The Tukey average test was performed at $5 \%$ probability of error for ion concentrations between precipitation, throughfall and stemflow. In order to verify the dilution effect, Pearson's correlations were applied between the volumes of rainfall partitions and the concentrations of ions. All statistical analyses were performed using SPSS 18.0 (SPSS Inc., Chicago, IL, USA).

\section{RESULTS AND DISCUSSION}

\subsection{Rainfall partitioning}

During the monitored period, the quantified precipitation was $1627 \mathrm{~mm}$. The month of December 2017 had the highest volume of R $371 \mathrm{~mm}$, while the months of July 2017 and April 2018 registered the lowest volumes $(0.00$ and $21 \mathrm{~mm})$ (Figure 3$)$.

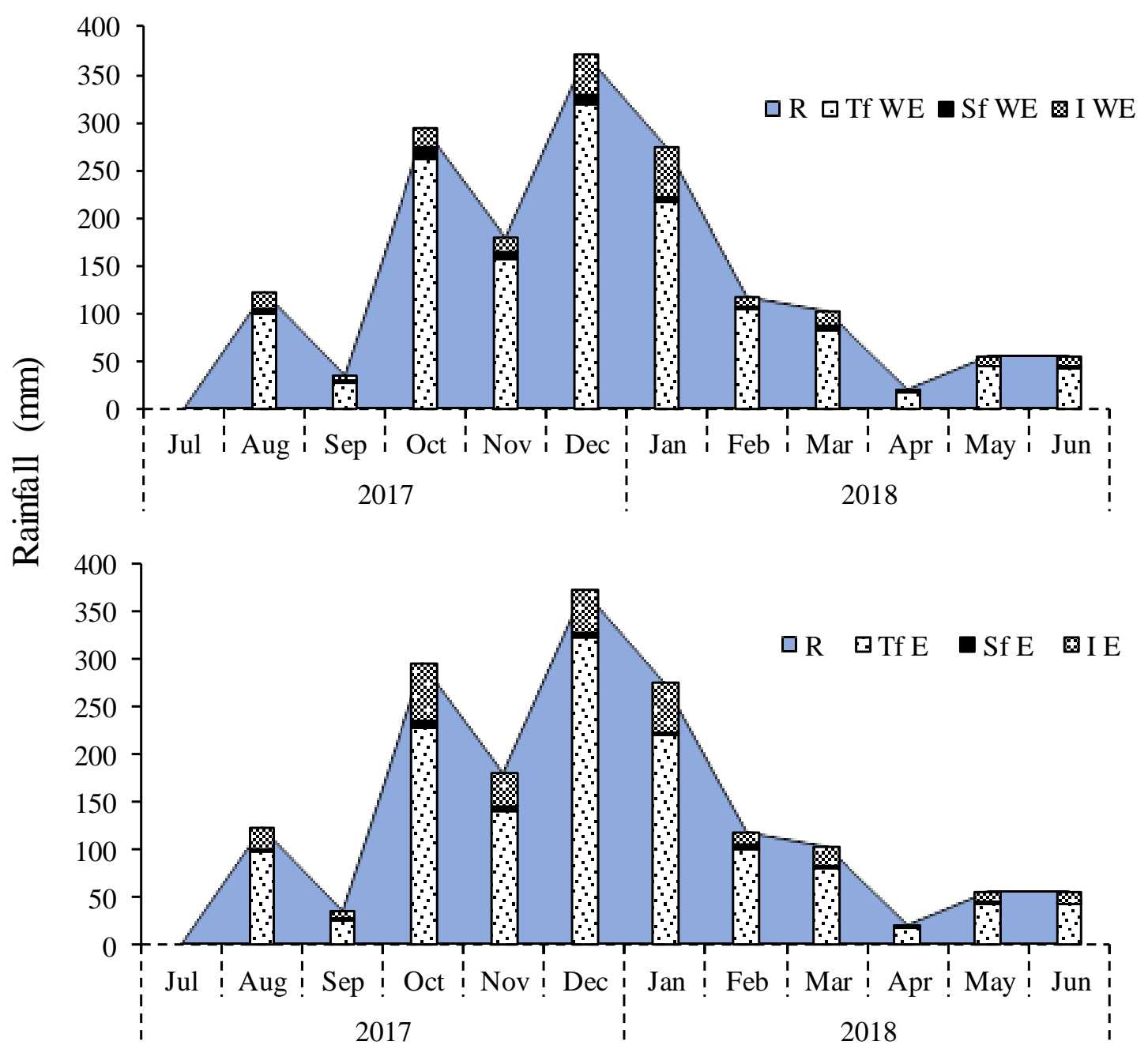

Figure 3. Temporal variation of the partition of pluviometric precipitation.

Regarding throughfall, the WE treatment showed $1379 \mathrm{~mm}$, equivalent to $84.8 \%$ of the precipitation. In contrast, the $\mathrm{E}$ treatment showed a lower value $(1311 \mathrm{~mm})$, corresponding to $80.6 \%$ of the precipitation. The volume collected for the Sf WE treatment was $48.40 \mathrm{~mm}$, representing $2.9 \%$ of the rainfall. For the Sf E treatment, $37 \mathrm{~mm}$ was accumulated, corresponding to $2.3 \%$ of the rainfall. In the canopy interception, the lowest observed value was 
$200 \mathrm{~mm}(12.3 \%)$ for WE treatment, while in treatment $\mathrm{E}$ the value was $280 \mathrm{~mm}$ (17.2\%) (Poleto et al., 2021).

\subsection{Chemical composition of rainfall, throughfall and stemflow}

In the evaluated period (Figure 3), the average $\mathrm{pH}$ value of rainfall was 6.17. The throughfall for the E and WE treatment of the throughfall was 5.94 and 5.96, respectively. Stemflow provided an average of 4.92 and 4.55 for the E and WE treatment of throughfall (Figure 4).

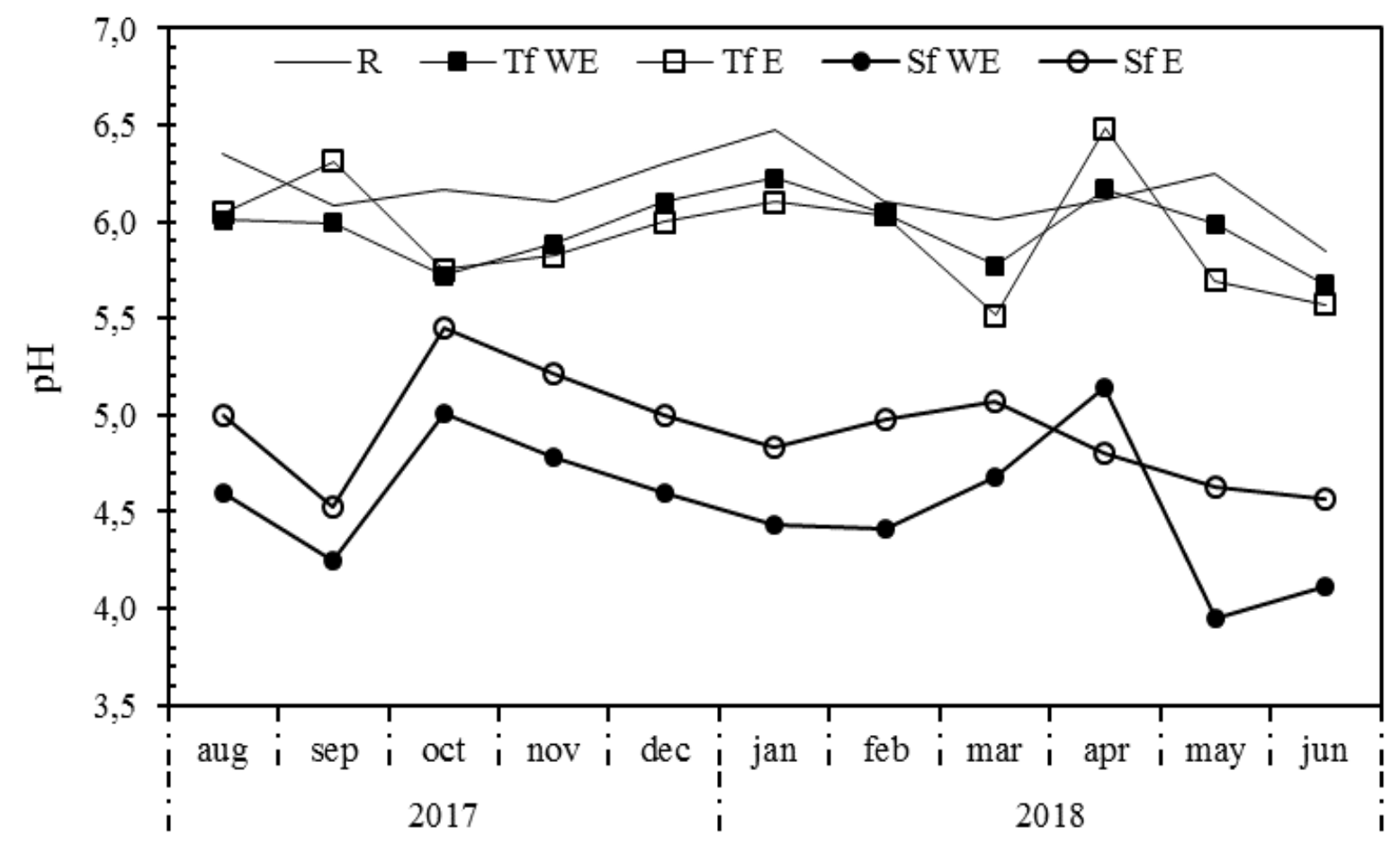

Figure 4. Average $\mathrm{pH}$ values of rainfall, throughfall and stemflow in the hybrid Eucalyptus urophylla $\mathrm{x}$ E. sp.

Momolli (2019b) found mean $\mathrm{pH}$ values of 4.57 for rainfall, 4.64 for throughfall and 5.54 for stemflow evaluation in a 7 to 8-year-old Eucalyptus dunnii stand in Alegrete, RS. Assessing the same species, from 4 to 5 years old, Dick et al. (2018) also found an increase in $\mathrm{pH}$ as precipitation interacts with the canopy. The $\mathrm{pH}$ was 4.3 in rainfall, 5.0 in the throughfall and 5.3 in the stemflow, respectively.

The ion concentration is variable as it interacts with the forest canopy. The $\mathrm{SO}_{4}{ }^{2-}$ and $\mathrm{Ca}^{2+}$ ions showed higher levels of rainfall, differing statistically from other rainfall partitions. Inverse behavior was observed with respect to $\mathrm{Cl}^{-}, \mathrm{Na}^{+}, \mathrm{N}_{-} \mathrm{NH}_{4}^{+}, \mathrm{K}^{+}, \mathrm{Mg}^{2+}$ ions that registered the greatest increases, especially in Stemflow and Throughfall. The ions $\mathrm{N}_{-} \mathrm{NO}_{2}{ }^{-}$and $\mathrm{P}-\mathrm{PO}_{4}{ }^{3-}$ showed no statistically significant difference. The mean test of the ions analyzed for each partition of the precipitation in the two water regimes can be verified in Table 1.

It is observed that the concentration of nutrients is influenced by the water regime, that is, during the months of higher rainfall, the ion concentrations are reduced while during the months of lower precipitation, the concentrations increase considerably. In the present study, the highest concentrations were recorded in the months of September, April and May, coinciding with the lowest rainfall. Other studies report the same behavior as in the case of Su et al. (2019) who monitored the chemical variation of rainwater in the different partitions in a mixed evergreen and deciduous broadleaved forest in Central China. 
Table 1. Chemical characteristics of water in precipitation, throughfall and stemflow during the monitoring period.

\begin{tabular}{|c|c|c|c|}
\hline \multirow{2}{*}{ Ion } & \multicolumn{3}{|c|}{ Concentration $\left(\mathrm{mg} \mathrm{L}^{-1}\right)$} \\
\hline & Precipitation & Throughfall & Stemflow \\
\hline \multicolumn{4}{|c|}{ Without exclusion } \\
\hline$* \mathrm{Cl}^{-}$ & $0.55 \pm 0.09^{\mathrm{a}}$ & $1.97 \pm 0.55^{b}$ & $3.86 \pm 0.73^{c}$ \\
\hline $\mathrm{N}-\mathrm{NO}_{2}^{-}$ & $0.04 \pm 0.00^{\mathrm{a}}$ & $0.04 \pm 0.00^{\mathrm{a}}$ & n.d \\
\hline $\mathrm{N}-\mathrm{NO}_{3}{ }^{-}$ & $0.12 \pm 0.03^{\mathrm{a}}$ & $0.16 \pm 0.04^{\mathrm{a}}$ & $0.15 \pm 0.04^{\mathrm{a}}$ \\
\hline $\mathrm{P}-\mathrm{PO}_{4}{ }^{3-}$ & $0.06 \pm 0.00^{\mathrm{a}}$ & $0.07 \pm 0.00^{\mathrm{a}}$ & $0.08 \pm 0.00^{\mathrm{a}}$ \\
\hline$* \mathrm{SO}_{4}{ }^{2-}$ & $0.15 \pm 0.02^{b}$ & $0.15 \pm 0.02^{b}$ & $0.08 \pm 0.01^{\mathrm{a}}$ \\
\hline$* \mathrm{Na}^{+}$ & $0.78 \pm 0.36^{\mathrm{a}}$ & $0.78 \pm 0.25^{\mathrm{a}}$ & $1.69 \pm 0.29^{b}$ \\
\hline$* \mathrm{~N}-\mathrm{NH}_{4}{ }^{+}$ & $0.13 \pm 0.05^{\mathrm{a}}$ & $0.16 \pm 0.03^{a}$ & $0.27 \pm 0.03^{b}$ \\
\hline$* \mathrm{~K}^{+}$ & $0.94 \pm 0.43^{a}$ & $2.51 \pm 0.69^{b}$ & $5.42 \pm 0.83^{c}$ \\
\hline$* \mathrm{Mg}^{2+}$ & $0.30 \pm 0.12^{\mathrm{a}}$ & $0.32 \pm 0.08^{a}$ & $1.23 \pm 0.18^{b}$ \\
\hline$* \mathrm{Ca}^{2+}$ & $2.44 \pm 0.57^{\mathrm{b}}$ & $0.99 \pm 0.20^{\mathrm{a}}$ & $1.69 \pm 0.33^{b}$ \\
\hline \multirow{2}{*}{ Ion } & Precipitation & Throughfall & Stemflow \\
\hline & \multicolumn{3}{|c|}{ Exclusion } \\
\hline$* \mathrm{Cl}^{-}$ & $0.55 \pm 0.09^{a}$ & $1.49 \pm 0.35^{b}$ & $4.19 \pm 0.93^{c}$ \\
\hline $\mathrm{N}-\mathrm{NO}_{2}{ }^{-}$ & $0.04 \pm 0.00^{\mathrm{a}}$ & $0.04 \pm 0.01^{\mathrm{a}}$ & $0.06 \pm 0.00^{\mathrm{a}}$ \\
\hline$* \mathrm{~N}-\mathrm{NO}_{3}{ }^{-}$ & $0.12 \pm 0.03^{\mathrm{a}}$ & $0.17 \pm 0.05^{a b}$ & $0.24 \pm 0.09^{b}$ \\
\hline $\mathrm{P}-\mathrm{PO}_{4}{ }^{3-}$ & $0.06 \pm 0.00^{\mathrm{a}}$ & $0.05 \pm 0.00^{\mathrm{a}}$ & $0.05 \pm 0.00^{\mathrm{a}}$ \\
\hline$* \mathrm{SO}_{4}{ }^{2-}$ & $0.15 \pm 0.02^{b}$ & $0.14 \pm 0.02^{b}$ & $0.08 \pm 0.01^{\mathrm{a}}$ \\
\hline$* \mathrm{Na}^{+}$ & $0.78 \pm 0.36^{\mathrm{a}}$ & $0.75 \pm 0.22^{a}$ & $1.83 \pm 0.33^{b}$ \\
\hline${ }^{*} \mathrm{~N}-\mathrm{NH}_{4}{ }^{+}$ & $0.13 \pm 0.05^{a b}$ & $0.09 \pm 0.02^{\mathrm{a}}$ & $0.19 \pm 0.06^{b}$ \\
\hline$* \mathrm{~K}^{+}$ & $0.94 \pm 0.43^{a}$ & $2.71 \pm 0.53^{b}$ & $6.27 \pm 0.96^{\mathrm{c}}$ \\
\hline$* \mathrm{Mg}^{2+}$ & $0.30 \pm 0.12^{a}$ & $0.36 \pm 0.09^{a}$ & $1.45 \pm 0.23^{b}$ \\
\hline$* \mathrm{Ca}^{2+}$ & $2.44 \pm 0.57^{\mathrm{c}}$ & $0.79 \pm 0.18^{\mathrm{a}}$ & $1.66 \pm 0.33^{b}$ \\
\hline
\end{tabular}

(*) Different letters in the same row indicate statistical differences at $\mathrm{p}<0.05$.

The verification of the ion dilution effect as a function of the precipitated rainfall volume 
is verified with the Pearson correlation test presented in Table 2. Mostly, a negative correlation was observed for more than $90 \%$ of the ions in the different precipitation partitions. In addition, there were strong significant correlations to a $<1 \%$ error probability for $\mathrm{K}^{+}, \mathrm{Ca}^{2+}$ and $\mathrm{Mg}^{2+}$ ions and for many throughfall ions.

Table 2. Pearson's correlation between ion concentration and measured water volume.

\begin{tabular}{cccccc}
\hline & \multicolumn{5}{c}{ Measured volume } \\
\cline { 2 - 6 } & $\mathrm{R}$ & $\mathrm{Tf}$ WE & $\mathrm{TfE}$ & $\mathrm{Sf} \mathrm{WE}$ & $\mathrm{SfE}$ \\
\hline $\mathrm{Cl}^{-}$ & -0.31 & $-0.70^{* *}$ & $-0.62^{*}$ & $-0.51^{*}$ & -0.48 \\
$\mathrm{NO}_{2}{ }^{-}$ & $0.56^{*}$ & $1.00^{* *}$ & 0.24 & - & - \\
$\mathrm{NO}_{3}{ }^{-}$ & -0.38 & -0.15 & -0.22 & -0.37 & $-0.53^{*}$ \\
$\mathrm{PO}_{4}{ }^{3-}$ & 0.05 & $-0.90^{* *}$ & - & 0.35 & $1.00^{* *}$ \\
$\mathrm{SO}_{4}{ }^{2-}$ & $-0.54^{*}$ & -0.46 & -0.29 & -0.05 & 0.06 \\
$\mathrm{Na}^{+}$ & -0.36 & -0.41 & $-0.53^{*}$ & $-0.55^{*}$ & -0.40 \\
$\mathrm{NH}_{4}^{+}$ & $-0.51^{*}$ & -0.20 & 0.28 & -0.49 & -0.35 \\
$\mathrm{~K}^{+}$ & -0.41 & $-0.78^{* *}$ & $-0.67^{*}$ & $-0.64 *$ & $-0.72^{* *}$ \\
$\mathrm{Mg}^{2+}$ & $-0.62^{*}$ & $-0.64^{*}$ & $-0.51^{*}$ & $-0.61^{*}$ & $-0.76^{* *}$ \\
$\mathrm{Ca}^{2+}$ & -0.43 & $-0.72^{* *}$ & $-0.53^{*}$ & $-0.73^{* *}$ & $-0.76^{* *}$ \\
\hline
\end{tabular}

**. Correlation is significant at the 0.01 level (2-tailled).

*. Correlation is significant at the 0.05 level (2-tailled).

Figure 5 shows in detail the variation in ion concentration over the monitored period for the different partitions of rainfall. As can be seen, for most ions there are two months of prominence: September and May.

The order of the ion contents in rainfall was: $\mathrm{Ca}^{2+}>\mathrm{K}^{+}>\mathrm{Na}^{+}>\mathrm{Cl}^{-}>\mathrm{Mg}^{2+}>\mathrm{SO}_{4}{ }^{2-}>\mathrm{N}-$ $\mathrm{NH}_{4}{ }^{+}>\mathrm{N}-\mathrm{NO}_{3}{ }^{-}>\mathrm{P}_{-} \mathrm{PO}_{4}{ }^{3-}>\mathrm{N}-\mathrm{NO}_{2}$. In the throughfall for the WE treatment, it was: $\mathrm{K}^{+}>\mathrm{Cl}^{-}>$ $\mathrm{Ca}^{2+}>\mathrm{Na}^{+}>\mathrm{Mg}^{2+}>\mathrm{N}^{2} \mathrm{NO}_{3}{ }^{-}>\mathrm{N}_{-}-\mathrm{NH}_{4}{ }^{+}>\mathrm{SO}_{4}{ }^{2-}>\mathrm{P}_{-} \mathrm{PO}_{4}{ }^{3}>\mathrm{N}-\mathrm{NO}_{2}{ }^{-}$. In the throughfall for the E treatment, it was: $\mathrm{K}^{+}>\mathrm{Cl}^{-}>\mathrm{Ca}^{2+}>\mathrm{Na}^{+}>\mathrm{Mg}^{2+}>\mathrm{N}^{2} \mathrm{NO}_{3}{ }^{-}>\mathrm{SO}_{4}{ }^{2-}>\mathrm{N}-\mathrm{NH}_{4}{ }^{+}>\mathrm{P}_{-} \mathrm{PO}_{4}{ }^{3}>\mathrm{N}-$ $\mathrm{NO}_{2}$.

For stemflow, the ion concentration was $\mathrm{K}^{+}>\mathrm{Cl}^{-}>\mathrm{Na}^{+}>\mathrm{Ca}^{2+}>\mathrm{Mg}^{2+}>\mathrm{N}_{-} \mathrm{NH}_{4}^{+}>\mathrm{N}-$ $\mathrm{NO}_{3}{ }^{-}>\mathrm{SO}_{4}{ }^{2-}>\mathrm{P}-\mathrm{PO}_{4}{ }^{3}>\mathrm{N}-\mathrm{NO}_{2}{ }^{-}$for the treatment without exclusion and $\mathrm{K}^{+}>\mathrm{Cl}^{-}>\mathrm{Na}^{+}>\mathrm{Ca}^{2+}$ $>\mathrm{Mg}^{2+}>\mathrm{N}-\mathrm{NO}_{3}{ }^{-}>\mathrm{N}-\mathrm{NH}_{4}{ }^{+}>\mathrm{SO}_{4}{ }^{2-}>\mathrm{N}-\mathrm{NO}_{2}{ }^{-}>\mathrm{P}_{-} \mathrm{PO}_{4}{ }^{3}$ for treatment with partial removal of throughfall.

Our results clearly show an increase in the contents of certain nutrients as the rainwater interacts with the forest canopy. Balieiro et al. (2007), evaluating a Eucalyptus stand in Seropédica, RJ found concentrations $\left(\mathrm{mg} \mathrm{L}^{-1}\right)$ of $0.82 ; 0.20 ; 3.52 ; 0.62 ; 0.39$ and 1.44 for N$\mathrm{NH}_{4}^{+}, \mathrm{P}, \mathrm{K}^{+}, \mathrm{Ca}^{2+}, \mathrm{Mg}^{2+}$ and $\mathrm{Na}^{+}$, respectively. For throughfall, the concentrations of $1.38 ; 0.33$; 14.83; 0.94; 0.96 and $3.78 \mathrm{mg} \mathrm{L}^{-1}$, for $\mathrm{N}^{-N_{H}}{ }^{+}, \mathrm{P}^{+} \mathrm{K}^{+}, \mathrm{Ca}^{2+}, \mathrm{Mg}^{2+}$ and $\mathrm{Na}^{+}$, respectively. In stemflow, the concentrations were as follows: $2.28 ; 0.40 ; 14.17 ; 0.75 ; 1.42$ and 2.73 for $\mathrm{N}$ $\mathrm{NH}_{4}^{+}, \mathrm{P}, \mathrm{K}^{+}, \mathrm{Ca}^{2+}, \mathrm{Mg}^{2+}$ and $\mathrm{Na}^{+}$, respectively. 

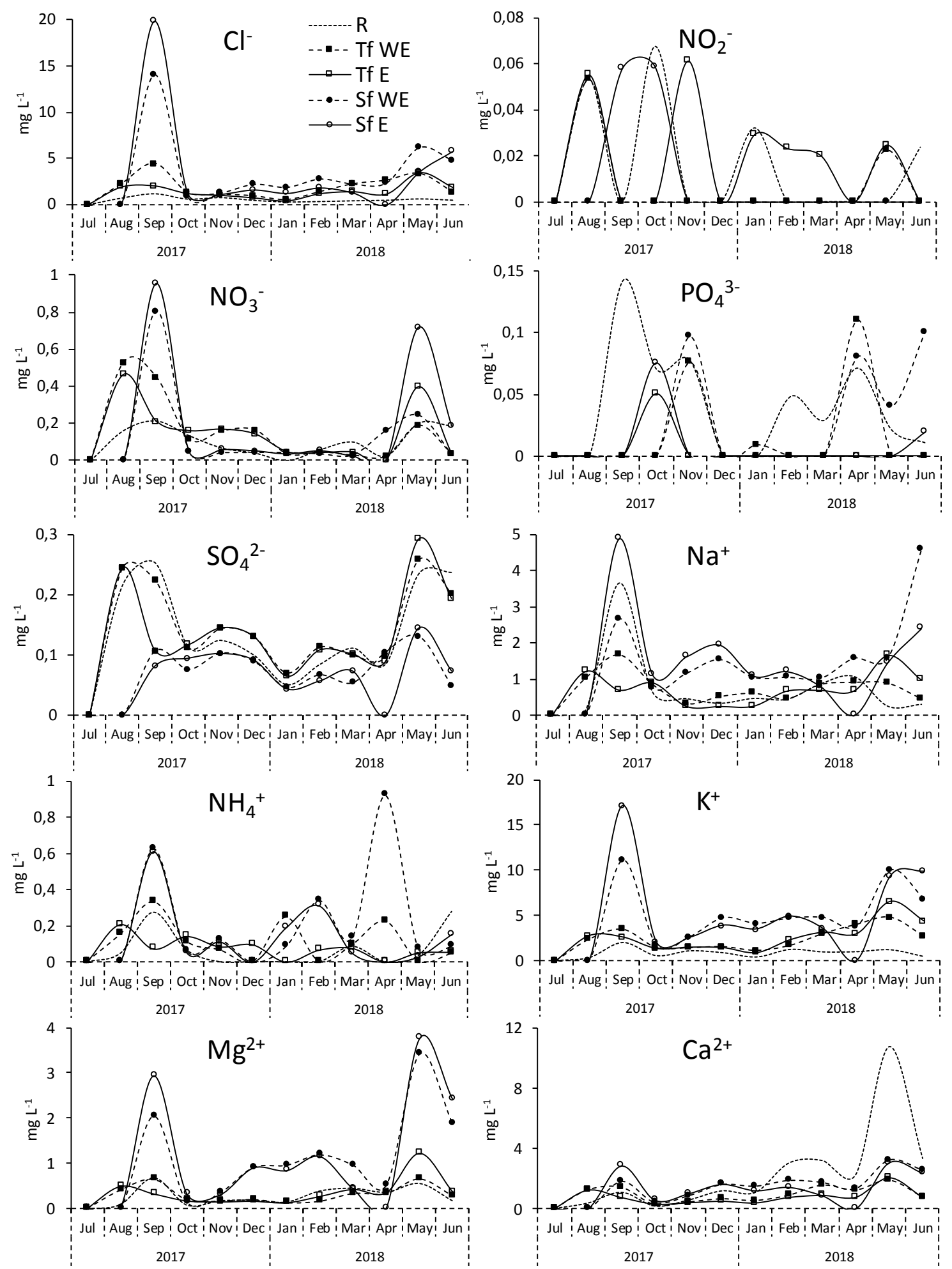

Figure 5. Monthly variation in ion concentration in different precipitation partitions.

\subsection{Nutrient input}

The rainfall had a total nutrient input of $55.69 \mathrm{~kg} \mathrm{ha}^{-1} \mathrm{yr}^{-1}$. For throughfall, the contribution was $60.20 \mathrm{~kg} \mathrm{ha}^{-1}$ and $36.27 \mathrm{~kg} \mathrm{ha}^{-1}$ for TfWE and TfE, respectively. The significant reduction in the amount of nutrients in treatment $E$ refers to the fact that these nutrients are being carried out of the stand due to the system of excluding water from rainfall. For stemflow, the contribution was greater, with $3.96 \mathrm{~kg} \mathrm{ha}^{-1}$ in the SfWE and 3.36 in the SfE (Figure 6). 

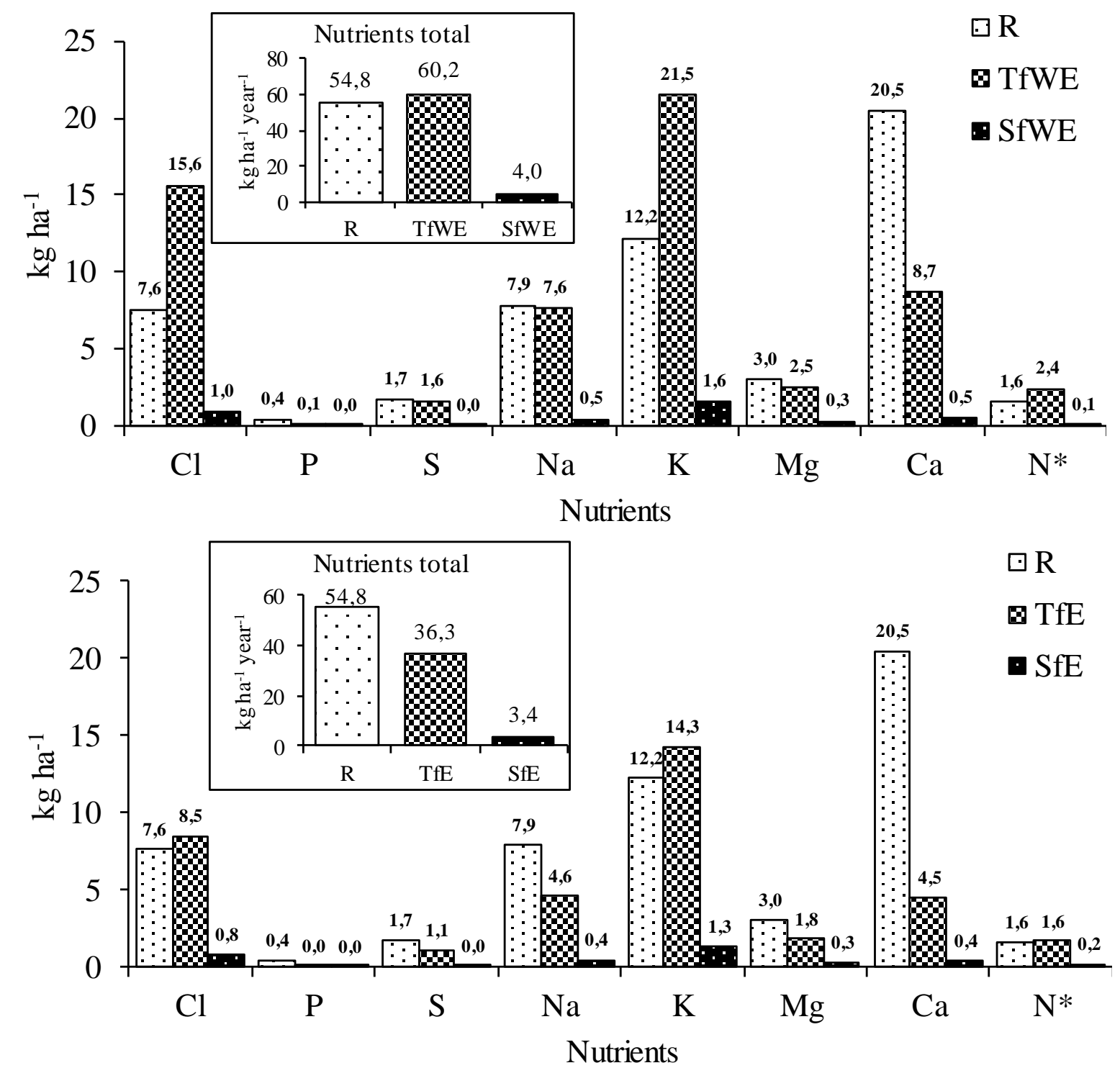

Figure 6. Annual amount of nutrients $\left(\mathrm{kg} \mathrm{ha}^{-1} \mathrm{yr}^{-1}\right)$ incorporated into the system by rainfall (R), throughfall (Tf) and stemflow (Sf) in a stand of the hybrid Eucalyptus urophylla x E. sp.

$* \mathrm{~N}$ total $=\mathrm{NO}_{2}{ }^{-}+\mathrm{NO}_{3}{ }^{-}+\mathrm{NH}_{4}{ }^{+}$.

The flow of nutrients in rainfall had the following distribution order: $\mathrm{Ca}>\mathrm{K}>\mathrm{Na}>\mathrm{Cl}>$ $\mathrm{Mg}>\mathrm{S}>\mathrm{N}>\mathrm{P}$. In Tf WE, the order was as follows: $\mathrm{K}>\mathrm{Cl}>\mathrm{Ca}>\mathrm{Na}>\mathrm{Mg}>\mathrm{N}>\mathrm{S}>\mathrm{P}$. In the $\mathrm{Sf}$ $\mathrm{WE}, \mathrm{K}>\mathrm{Cl}>\mathrm{Ca}>\mathrm{Na}>\mathrm{Mg}>\mathrm{N}>\mathrm{S}>\mathrm{P}$. The Tf E presented the following order: $\mathrm{K}>\mathrm{Cl}>\mathrm{Na}>$ $\mathrm{Ca}>\mathrm{Mg}>\mathrm{N}>\mathrm{S}>\mathrm{P}$. For $\mathrm{SfE} \mathrm{K}>\mathrm{Cl}>\mathrm{Na}>\mathrm{Ca}>\mathrm{Mg}>\mathrm{N}>\mathrm{S}>\mathrm{P}$. Considering the sum of throughfall plus stemflow in the WE treatment the amount of nutrients $\left(\mathrm{kg} \mathrm{ha}^{-1}\right)$ was 16.6 for $\mathrm{Cl}, 0.1$ for $\mathrm{P}, 1.7$ for $\mathrm{S}, 8.1$ for $\mathrm{Na}, 23.1$ for $\mathrm{K}, 2.9$ for $\mathrm{Mg}, 9.2$ for $\mathrm{Ca}$ and 2.5 for $\mathrm{N}$. As for treatment $\mathrm{E}$, there was a contribution $\left(\mathrm{kg} \mathrm{ha}^{-1} \mathrm{yr}^{-1}\right)$ of 9.3 for $\mathrm{Cl}, 0.02$ for $\mathrm{P}, 1.1$ for $\mathrm{S}, 5.0$ for $\mathrm{Na}, 15.6$ for $\mathrm{K}, 2.1$ for $\mathrm{Mg}$, 4.9 for $\mathrm{Ca}, 1.8$ for $\mathrm{N}$.

Regarding nutrient input via rainfall, it was observed that there was a significant increase in nutrients in the aqueous solution, whose input sequence was $\mathrm{K}>\mathrm{S}>\mathrm{Ca}>\mathrm{N}>\mathrm{Mg}$. These inputs could reduce the addition of $22 \%$ and $11 \%$ of the amounts of $\mathrm{K}$ and $\mathrm{N}$, respectively, applied to pre-planting fertilization (Dick et al., 2018). The annual contribution of nutrients in the present study is similar to that found by Momolli et al., (2020). For these authors, the annual contribution was $36.3 \mathrm{~kg} \mathrm{ha}^{-1}$. This small variation is justified according to the conditions: close to the ocean, emission of atmospheric pollutants by anthropic activity and even soil and environmental characteristics (Corti et al., 2019; Yuan et al., 2017). Possibly, the greatest 
contribution of certain nutrients is related to the existence of two pulp mills, the first approximately $12 \mathrm{~km}$ away in a straight line located in the municipality of Telêmaco Borba, PR and the second approximately $21 \mathrm{~km}$ away in the municipality of Ortigueira, PR. Balieiro et al. (2007) in an Eucalyptus stand found a contribution $\left(\mathrm{kg} \mathrm{ha}^{-1}\right)$ via rainfall of $12.07 \mathrm{~N}^{-\mathrm{NH}_{4}}{ }^{+} ; 2.65$ P; 86.00 K+; $12.25 \mathrm{Ca}^{2+} ; 9.24 \mathrm{Mg}^{2+} ; 29.81 \mathrm{Na}^{+}$.

The increase in the amount of nutrients after interaction with the canopy is more significant for $\mathrm{K}^{+}$, which can be attributed to the high levels due to leaching of the canopy of the trees. However, some ions do not exhibit the same behavior as $\mathrm{SO}_{4}{ }^{2-}$. The input via rainfall was 1.7 $\mathrm{kg} \mathrm{ha}^{-1}$ and $1.6 \mathrm{~kg} \mathrm{ha}^{-1}$ via TfWE. According to Gay and Murphy (1985), approximately between $30-70 \%$ of the dry deposition of $\mathrm{SO}_{4}{ }^{2-}$ can be retained in the canopy. Corrêa et al. (2019) evaluating an E. dunni stand 16.5 months old, found that due to the concentration of ions there was a greater contribution of elements after the interaction of precipitation with the forest canopy.

\section{CONCLUSION}

There was an enrichment of nutrients as the water interacted with the forest canopy. Considering the average levels of ions, the degree of enrichment had the following decreasing order: stemflow > throughfall > rainfall. The concentration of ions is seasonal and is especially determined by the volume of water in each partition causing the dilution effect.

The total quantity of nutrients contributed had the following order: throughfall > rainfall > stemflow. The reduction of the water treatment system in partial exclusion of precipitation (E) reduced representative nutrient input. It is important to highlight that although stemflow represents on average only $2.6 \%$ of the water volume, it is responsible for $6.7 \%$ of the amount of nutrients in relation to precipitation. Therefore, stemflow cannot be neglected in the balance of nutrient cycling.

Considering the interaction of rainwater with canopy, in a 7-year rotation there is a potential reduction of chemical fertilizers. These results point the way to greater economic and environmental sustainability.

\section{ACKNOWLEDGEMENTS}

This study was financed in part by the Coordenação de Aperfeiçoamento de Pessoal de Nível Superior - Brasil (CAPES) - Finance Code 001.

\section{DATA AVAILABILITY STATEMENT}

The data that support the findings of this study are available on request from the corresponding author. The data are not publicly available due to privacy or ethical restrictions.

\section{REFERENCES}

ALLAN, R. P.; SODEN, B. J. Atmospheric warming and the amplification of precipitation extremes. Science, v. 321, p. 1481-1484, 2008. https://doi.org/10.1126/science.1160787

ALVARES, C. A. et al. Köppen's climate classification map for Brazil. Meteorologische Zeitschrift, v. 22, n. 6, p. 711-728, 2014. https://doi.org/10.1127/0941-2948/2013/0507

ANDRE, F.; JONARD, M.; PONETTE, Q. Effects of biological and meteorological factors on stemflow chemistry within a temperate mixed oak-beech stand. Science of the Total Environment, v. 393, p. 72-83, 2008. https://doi.org/10.1016/j.scitotenv.2007.12.002 
APHA; AWWA; WEF. Standard Methods for the Examination of Water and Wastewater. 20. ed. Washington, 1998.

BALIEIRO, F. C.; FRANCO, A. A.; FONTES, R. L. F.; DIAS, L. E.; CAMPELLO, E. F. C.; FARIA, S. M. Evaluation of the throughfall stemflow nutrient contents in mixed and pure plantations of Acacia mangium, Pseudosamenea guachapele and Eucalyptus grandis. Revista Árvore, v. 31 n. 2, p. 339-346, 2007. https://doi.org/10.1590/S010067622007000200017

BINKLEY, D.; CAMPOE, O. C.; ALVARES, C.; CARNEIRO, R. L.; CEGATTA, Í; STAPE, J. L. The interactions of climate, spacing and genetics on clonal Eucalyptus plantations across Brazil and Uruguay. Forest Ecology and Management, v. 405, p. 271-283, 2017. https://doi.org/10.1016/j.foreco.2017.09.050

BHAT, S.; JACOBS, J.; BRYANT, M. The chemical composition of rainfall and throughfall in five forest communities: A case study in Fort Benning, Georgia. Water, Air, \& Soil Pollution, v. 218, p. 323-332, 2011. https://doi.org/10.1007/s11270-010-0644-1

CHAFFE, P. L. B.; KOBIYAMA, M.; YAMASHIKI, K.; TAKARA, K. Is interception information important for rainfall runoff modeling? Annual Journal of Hydraulic Engineering, v. 54, p. 73-78, 2010.

CORRÊA, R. S.; SCHUMACHER, M. V.; MOMOLLI, D. R.; BERGER, C. Aspectos da precipitação pluviométrica em um povoamento jovem de Eucalyptus dunnii no Bioma Pampa. Advances in Forestry Science, v. 6, n. 3, p. 717-721, 2019. http://dx.doi.org/10.34062/afs.v6i3.7617

CORTI, G.; AGNELLI, A.; COCCO, S.; CARDELLI, V.; MASSE, J.; COURCHESNE, F. Soil a_ects throughfall and stemflow under Turkey oak (Quercus cerris L.). Geoderma, v. 333, p. 43-56, 2019.

DAWOE, E. K.; BARNES, V. R.; OPPONG, S. K. Spatio-temporal dynamics of gross rainfall partitioning and nutrient fluxes in shaded-cocoa (Theobroma cocoa) systems in a tropical semi-deciduous forest. Agroforestry Systems, v. 92, p. 397-413, 2018. https://doi.org/10.1007/s10457-017-0108-3

DICK, G. et al. Nutrient input via incident rainfall in a Eucalyptus dunnii stand in the Pama Biome. Floresta e Ambiente, v. 25, n. 3, 2018. https://doi.org/10.1590/21798087.055916

FAN, J. L.; OESTERGAARD, K. T.; GUYOT, A.; JENSEN, D. G.; LOCKINGTON, D. A. Spatial variability of throughfall and stemflow in an exotic pine plantation of subtropical coastal Australia. Hydrological Processes, v. 29, p. 793-804, 2015. https://doi.org/10.1002/hyp.10193

FERRAZ, S. F. B.; RODRIGUES, C. B.; GARCIA, L. G.; ALVARES, C. A.; DE PAULA LIMA, W. Effects of Eucalyptus plantations on streamflow in Brazil: Moving beyond the water use debate. Forest Ecology and Management, v. 453, p. 117571, 2019.

FLORES, T. B. et al. Eucalyptus no Brasil: zoneamento climático e guia para identificação. Piracicaba: IPEF, 2016. 448p.

GAY, D. W.; MURPHY, C. E. The Deposition of SO44- on Forests (Final Report, EPRI Project R.P. 1813-2). Palo Alto: Electric Power Research Institute, 1985.

IBÁ. Relatório anual 2020: ano base 2019. São Paulo: 2020. 66 p. 
JOHNSON, M. S.; LEHMANN, J. Double-funneling of trees: Stemflow and root-induced preferential flow. Ecoscience, v. 13, p. 324-333, 2006. https://doi.org/10.2980/i11956860-13-3-324.1

LEVIA, D. F.; KEIM, R. F.; CARLYLE-MOSES, D. E.; FROST, E. E. Throughfall and stemflow in wooded ecosystems. In: LEVIA, D.; CARLYLE-MOSES, D.; TANAKA, T. (eds.). Forest Hydrology and Biogeochemistry: Synthesis of Past Research and Future Directions. Ecological Studies, 216). Dordrecht: Springer, 2011. https://doi.org/10.1007/978-94-007-1363-5

LIKENS, G.E. Biogeochemistry of a Forested Ecosystem. Berlin: Springer Science \& Business Media, 2013.

LLORENS, P.; DOMINGO, F. Rainfall partitioning by vegetation under Mediterranean conditions: A review of studies in Europe. Journal of Hydrology, v. 335, p. 37-54, 2007. https://doi.org/10.1016/j.jhydrol.2006.10.032

LU, J.; ZHANG, S.; FANG, J.; YAN, H.; LI, J. Nutrient fluxes in rainfall, throughfall, and stemflow in Pinus densata natural forest of Tibetan Plateau. Clean Soil Air Water, v. 45, p. 1600008, 2017. https://doi.org/10.1002/clen.201600008

MOMOLLI, D. R.; SCHUMACHER, M. V.; VIERA, M.; LUDVICHAK, A. A.; GUIMARÃES, C. C.; SOUZA, H. P. Incident precipitation partitioning: throughfall, stemflow and canopy interception in Eucalyptus dunnii stand. Journal of Agricultural Science, v. 11, n. 5, 2019a. https://doi.org/10.5539/jas.v11n5p372

MOMOLLI, D. R.; SCHUMACHER, M. V.; VIERA, M.; LUDVICHAK, A. A.; GUIMARÃES, C. C.; SOUZA, H. P. Incident Precipitation Partitioning: The Canopy Interactions Enrich Water Solution with Nutrients in Throughfall and Stemflow. Journal of Agricultural Science, v. 11, n. 6, 2019b. https://doi.org/10.5539/jas.v11n6p351

MOMOLLI, D. R.; SOUZA, H. P.; SCHUMACHER, M. V.; LUDVICHAK, A. P.; GUIMARÃES, C. C.; MALHEIROS, A. C.; GONSALVES, J. M. W. Seasonal variation of atmospheric nutrient deposition in the western part of Rio Grande do Sul, Brazil. Revista Ambiente \& Água, v. 15, n. 3, 2020. https://doi.org/10.4136/ambi-agua.2524

NAVAR, J.; GONZALEZ, J. M.; GONZALEZ, H. Gross precipitation and throughfall chemistry in legume species planted in Northeastern Mexico. Plant Soil, v. 318, p. 1526, 2009. https://doi.org/10.1007/s11104-008-9812-0

NAVAR, J. Stemflow variation in Mexico's northeastern forest communities: Its contribution to soil moisture content and aquifer recharge. Journal of Hydrology, v. 408, n.1, p. 35 42, 2011. https://doi.org/10.1016/j.jhydrol.2011.07.006

POLETO, G. C.; MOMOLLI, D. R.; SCHUMACHER, M. V.; LUDVICHAK, A. A.; SANTOS, K. F.; STAHL, J.; ALVARES, C. A. Partial exclusion of precipitation: throughfall, stemflow and canopy interception in Eucalyptus plantations in southern Brazil. Revista Ambiente \& Água, v. 16, n. 5, 2021. https://doi.org/10.4136/ambiagua. 2645

PREUHSLER, T.; BASTRUP-BIRK, A.; BEUKER, E. (elab.). Meteorological Measurements. In: United Nations Economic Commission for Europe. Manual on methods and criteria for harmonized sampling, assessment, monitoring and analysis of the effects of air pollution on forests. Part VII. 2006. Available at: https://www.icpforests.org/pdf/manual/2000/Chapt7_compl2006.pdf Access: Oct. 2021. 
SCHRUMPF, M.; ZECH, W.; AXMACHER, J.; HERBERT V. M. L. Biogeochemistry of an Afrotropical Montane Rain Forest on Mt. Kilimanjaro, Tanzania. Journal of Tropical Ecology, v. 22, n. 1, p. 77-89. 2006. http://www.jstor.org/stable/4092145

STAELENS, J.; DE SCHRIJVER, A.; VERHEYEN, K.; VERHOEST, N. E. C. Spatial variability and temporal stability of throughfall water under a dominant beech (Fagus sylvatica L.) tree in relationship to canopy cover. Journal of Hydrology, v. 330, p. 651662, 2006. https://doi.org/10.1016/j.jhydrol.2006.04.032

SU, L.; ZHAO, C.; XU, W.; XIE, Z. Hydrochemical Fluxes in Bulk Precipitation, Throughfall, and Stemflow in a Mixed Evergreen and Deciduous Broadleaved Forest. Forests, v. 10, n. 507, 2019. https://doi.org/10.3390/f10060507

SWAFFER, B. A.; HOLLAND, K. L.; DOODY, T. M.; HUTSON, J. Rainfall partitioning, tree form and measurement scale: A comparison of two co-occurring, morphologically distinct tree species in a semi-arid environment. Ecohydrology, v. 7, p. 1331-1344, 2014. https://doi.org/10.1002/eco.1461

TIWARI, S. et al. Nature and Sources of Ionic Species in Precipitation across the Indo-Gangetic Plains, India. Aerosol and Air Quality Research, v. 16, n.4, p. 943.957, 2016. https://doi.org/10.4209/aaqr.2015.06.0423

VIERA, M.; SCHUMACHER, M. V. Deposição de serapilheira e de macronutrientes em um povoamento de acácia negra (Acacia mearnsii De Wild.) no Rio Grande do Sul. Ciência Florestal, v. 20, n.2, p. 225-233, 2010. https://doi.org/10.5902/198050981848

ZHANG, Y.; WANG, X.; HU, R.; PAN, Y.; ZHANG, H. Stemflow in two xerophytic shrubs and its significance to soil water and nutrient enrichment. Ecological Research, v. 28, p. 567-579, 2013. https://doi.org/10.1007/s11284-013-1046-9

ZHANG, Y.; WANG, X.; PAN, Y.; HU, R. Variations of Nutrients in Gross Rainfall, Stemflow, and Throughfall Within Revegetated Desert Ecosystems. Water Air Soil Pollution, v. 227, n. 6, p. 183, 2016. https://doi.org/10.1007/s11270-016-2878-z

ZHOU, X. et al. Chemical composition of precipitation in Shenzhen, a coastal mega-city in South China: Influence of urbanization and anthropogenic activities on acidity and ionic composition. Science of The Total Environment, v. 662, p. 218.226, 2019. https://doi.org/10.1016/j.scitotenv.2019.01.096

YUAN, C.; GAO, G.; FU, B. Comparisons of stemflow and its bio-/abiotic influential factors between two xerophytic shrub species. Hydrology and Earth System Sciences, v. 21, p. 1421-1438, 2017. https://doi.org/10.5194/hess-21-1421-2017 